\title{
KUALITAS DIET, STATUS GIZI DAN STATUS ANEMIA WANITA PRAKONSEPSI ANTARA DESA DAN KOTA
}

\author{
Diet Quality, Nutritional Status and Anemia among Preconception Women \\ between Rural and Urban Areas \\ Cindy Fariski ${ }^{1}$, Fillah Fithra Dieny ${ }^{1,2}$, Hartanti Sandi Wijayanti ${ }^{1,2}$ \\ 1 Departemen Imu Gizi Fakultas Kedokteran Universitas Diponegoro \\ ${ }^{2}$ Center of Nutrition Research (CENURE) Fakultas Kedokteran Universitas Diponegoro \\ E-mail: fillahdieny@gmail.com
}

\begin{abstract}
The health status during the preconception period was important to prepare pregnancy. Living patterns that can affect diet quality and nutritional status. This study aimed to analyze the differences in diet quality, nutritional status, and anemia between preconception women in rural and urban areas. This study was conducted using a cross-sectional design that consisted of 68 brides aged 16-35 years selected by consecutive sampling. Diet quality was obtained by diet quality index international (DQI-I) form. Nutritional status based on body mass index (BMI) and mid-upper arm circumference (MUAC). Hemoglobin levels were measured by the cyanmethemoglobin method. Data were analyzed by Independent T-test and Mann Whitney. Subjects in rural and urban areas had low diet quality. The score of variation in the type of protein intake, total fat, and saturated fat was higher in rural areas than urban areas $(p=0,001 ; p=0,013$; $p=0,002$ ). The mean BMI and MUAC were higher in urban subjects than rural subjects but the hemoglobin levels of rural subjects were higher than urban subjects. The subjects of anemia in urban was 23,5 percent were higher than rural was 14,7 percent but the risk of chronic energy deficiency in rural was $55,9 \%$ were higher than urban was 11,8 percent. There were no differences in diet quality and hemoglobin levels between preconception women in rural and urban areas $(p=0,990 ; p=0,116)$. There were a differences in BMI and MUAC $(p=0,026 ; p=<0,001)$. There were differences in nutritional status based on BMI and MUAC in both areas. There were no differences in diet quality and hemoglobin levels in rural and urban areas.
\end{abstract}

Keywords: preconception women, diet quality, nutritional status, anemia

\section{ABSTRAK}

Status kesehatan periode prakonsepsi berperan penting untuk mempersiapkan kehamilan. Keadaan wilayah tempat tinggal akan mempengaruhi akses pangan, informasi dan pola konsumsi masyarakatsehingga bisa mempengaruhi kualitas diet dan status gizi. Penelitian ini bertujuan untuk menganalisis perbedaan kualitas diet, status gizi dan stats anemia wanita prakonsepsi di wilayah desa dan kota. Penelitian ini menggunakan desain cross-sectional dengan 68 subjek pengantin wanita berusia 16-35 tahun dan dipilih dengan metode consecutive sampling. Kualitas diet diukurmenggunakan form Diet Quality Index International (DQI-I). Status gizi dilihat berdasarkan indeks massa tubuh (IMT) dan lingkar lengan atas (LILA). Kadar hemoglobin ( $\mathrm{Hb}$ ) diukur menggunakan metode cyanmethemoglobin. Analisis data dengan uji Independent t-test dan Mann Whitney. Hasil penelitian menunjukkan subjek di wilayah desa maupun kota memiliki kualitas diet rendah. Skor variasi jenis asupan protein, total lemak dan lemak jenuh lebih tinggi pada subjek desa dibandingkankota $(p=0,001 ; p=0,013 ; p=0,002)$. Rerata IMT dan LILA subjek kota lebih tinggi dibandingkan desa namun kadar hemoglobin subjek desa lebih tinggi dibandingkan kota. Subjek anemia di kota $(23,5 \%)$ lebih tinggi dibandingkan desa $(14,7 \%)$ namun risiko KEK di desa $(55,9 \%)$ lebih tinggi dibandingkan kota $(11,8 \%)$. Tidak ada perbedaan kualitas diet dan kadar hemoglobin antara subjek didesa dan $k$ ota $(p=0,990 ; p=0,116)$. Ada perbedaan status gizi berdasarkan IMT dan LILA antara subjek didesa dan kota $(p=0,026 ; p=<0,001)$. Simpulan: Ada perbedaan status gizi berdasarkan IMT dan LILA pada kedua wilayah. Tidak ada perbedaan kualitas diet dan kadar hemoglobin subjek wilayah desa dan kota.

Kata kunci: wanita prakonsepsi, kualitas diet, status gizi, anemia

Doi: $10.36457 /$ gizindo.v\%vi\%i.401

www.persagi.org/ejournal/index.php/Gizi_Indon 


\section{PENDAHULUAN}

W anita usia subur (WUS) merupakan kelompok daur hidup yang mempunyai peran penting dalam menentukan kualitas sumber daya manusia, karena wanita berperan dalam proses kehamilan hingga melahirkan keturunan ${ }^{1}$. Oleh karena itu penting untuk memperhatikan kesehatan pada masa prakonsepsi sebagai investasi kesehatan jangka panjang untuk ibu dan bayi.Hal ini sesuai dengan teori Life Course Theory (LCT) yang menyatakan bahwa hasil kelahiran dapat dipengaruhi oleh interaksi jangka panjang dari kondisi biologis, perilaku, dan psikologi/lingkungan (healthy food) wanita sebelum kehamilan. ${ }^{2}$

Menjaga status gizi optimal pada periode prakonsepsi merupakan waktu yang tepat untuk mengurangi risiko terjadinya masalah gizi saat kehamilan seperti kekurangan energi kronis (KEK). Menurut Riskesdas tahun 2013, prevalensi risiko KEK di Indonesia pada WUS tidak hamil sebesar 20,8 persen dan semakin meningkat pada WUS yang hamil yaitu sebesar

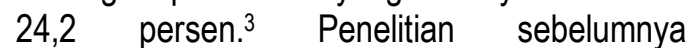
menjelaskan ibu hamil dengan KEK memiliki indeks massa tubuh (IMT) sebelum kehamilan dalam kategori underweight memiliki proporsi sampel tertinggi yaitu 57,5 persen. ${ }^{4} \mathrm{Hal}$ ini juga sesuai dengan penelitian tahun 2017 yang menyatakan bahwa ibu hamil yang sebelum hamil sudah underweight cenderung akan tetap underweight (KEK) pada saat kehamilan. ${ }^{5}$

Masalah kesehatan yang sering dialami wanita prakonsepsi selain KEK dan dapat mempengaruhi selama masa kehamilan adalah anemia. Wanita prakonsepsi adalah kelompok yang paling berisiko mengalami anemia karena mengalami siklus menstruasi setiap bulannya ${ }^{6}$. Kejadian anemia pada ibu hamil di Indonesia masih tergolong tinggi yaitu 37,1 persen. ${ }^{3}$ Secara global, prevalensi anemia pada wanita hamil 42 persen dan wanita tidak hamil sebesar 30 persen. $^{7}$ Menurut data WHO sebanyak 58 persen ibu hamil yang menderita anemia juga mengalami anemia sebelum kehamilan 6 .Oleh karena itu penting adanya tindakan pencegahan anemia mulai dari masa prakonsepsi.

Gizi prakonsepsi dan atau selama awal kehamilan (kehamilan $<12$ minggu) mempengaruhi proses perkembangan janin namun sebagian besar studi fokus pada masa kehamilan trimester kedua dan atau ketiga dimana proses utama seperti organogenesis telah selesai. KEK pada masa prakonsepsi dapat mempengaruhi perkembangan janin pada awal kehamilan karena kejadian KEK menyebabkan suplai zat gizi ke janin tidak optimal. Pasokan zat gizi ke janin selama kehamilan bergantung pada fungsi plasenta yang ditentukan pada awal kehamilan. 8,9 Apabila terjadi anemia pada masa prakonsepsi maka akan meningkatkan risiko anemia selama kehamilan dan bayi yang dilahirkan memiliki cadangan besi rendah serta juga dikaitkan dengan meningkatnya kelahiran prematur. ${ }^{10}$ Dengan demikian penting adanya penanganan masalah gizi pada masa prakonsepsi.

Terdapat perbedaan prevalensi kejadian anemia dan risiko KEK antara wanita di wilayah desa dan kota. Berdasarkan Riskesdas tahun 2013 prevalensi ibu hamil yang mengalami anemia di wilayah perdesaan sebesar 37,8 persen lebih tinggi dibandingkan wilayah perkotaan sebesar 36,4 persen. ${ }^{3}$ Selain anemia, prevalensi risiko KEK WUS tidak hamil di perdesaan sebesar 22,7 persen juga lebih tinggi dibandingkan perkotaan yaitu sebesar 19,1 persen. ${ }^{3}$

Faktor yang dapat mempengaruhi perbedaan kejadian anemia dan KEK pada wilayah desa dan kota yaitu keadaan sosial ekonomi, ketahanan pangan, akses pangan, pendidikan, pengetahuan, serta sosial budaya di desa dan kota. ${ }^{11,12,13,14}$ Faktor-faktor tersebut dapat mempengaruhi pola konsumsi masyarakat baik aspek kuantitas maupun kualitas di kedua wilayah.

Hasil penelitian sebelumnya mengungkapkan bahwa kualitas diet ibu hamil di wilayah desa lebih rendah dibandingkan wilayah kota. ${ }^{15}$ Kualitas diet dapat pengaruhi oleh kebudayaan tradisional terhadap pantangan makanan (food taboo). Di negara berkembang, kualitas diet ibu hamil masih tergolong rendah terutama di daerah perdesaan. Wanita perkotaan tidak mudah dipengaruhi budaya tradisional karena tingkat pendidikan wanita perkotaan lebih tinggi dan lebih mudah mengakses pengetahuan terkait gizi. ${ }^{16}$

Data dari Dinas Kesehatan Kabupaten Semarang menunjukkan angka kematian bayi (AKB) dan angka kematian ibu (AKI) di Kecamatan Sumowono paling tinggi 
dibandingkan 26 kecamatan lainnya di Kabupaten Semarang sejak tahun 2009 2014. ${ }^{17}$ Sementara itu, berdasarkan data dari Dinas Kesehatan Kota Semarang tahun 2016 dan 2017 menunjukkan bahwa angka kematian ibu (AKI) di Pedurungan paling tinggi dibandingkan 15 kecamatan lainnya di Kota Semarang. ${ }^{18}$ Data tersebut mengungkapkan bahwa baik di wilayah desa maupun kota kejadian kematian ibu masih ditemukan. Menurut WHO, persentase tertinggi penyebab kematian ibu adalah pendarahan (28\%) yang dapat disebabkan oleh anemia dan KEK. Ibu hamil yang berisiko KEK berpeluang menderita anemia 2,76 kali lebih besar dibandingkan dengan yang tidak berisiko. ${ }^{19}$

Belum banyak ditemukan penelitian mengenai kualitas diet dan status gizi yang berfokus pada masa prakonsepsi.Padahal bila ditemukan kualitas diet rendah, status gizi kurang dan status anemia pada kedua wilayah harus memberikan solusi penyelesaian masalah sesuai dengan karakteristik dan keadaan masyarakat di masing-masing wilayah. Oleh karena itu, peneliti ingin melihat perbandingan kualitas diet, status gizi dan status anemia wanita prakonsepsi di wilayah desa Kecamatan Sumowono, Kabupaten Semarang dan wilayah kota di Kecamatan Pedurungan, Kota Semarang.

\section{METODE PENELITIAN}

Penelitian ini termasuk dalam ruang lingkup gizi masyarakat dengan menggunakan desain cross-sectional. Penelitian dilaksanakan pada bulan Februari sampai Mei 2018 di KUA Kecamatan Sumowono, Kabupaten Semarang dan KUA Kecamatan Pedurungan, Kota Semarang.Populasi target dalam penelitian ini adalah pengantin wanita, sedangkan populasi terjangkaunya adalah pengantin wanita berusia 16-35 tahun yang terdaftar di KUA Kecamatan Sumowono, Kabupaten Semarang dan KUA Kecamatan Pedurungan, Kota Semarang. Besar sampel dihitung menggunakan rumus besar sampel untuk dua kelompok independent. Hasilnya, subjek yang dibutuhkan dalam penelitian ini masing-masing 34 orang sehingga total sebanyak 68 orang. Metode sampling dilakukan dengan cara consecutive sampling dan sesuai dengan kriteria inklusi. Kriteria inklusi penelitian ini adalah pengantin wanita tidak dalam kondisi hamil, tidak sedang mengalami penyakit kronis seperti infeksi cacing, gangguan ginjal dan HIVIAIDS, tidak merokok, dan bersedia mengisi formulir pernyataan kesediaan sebagai subjek penelitian. Kriteria eksklusi yaitu subjek tidak mengikuti penelitian sampai dengan selesai atau mengundurkan diri saat penelitian berlangsung.

Variabel terikat pada penelitian ini adalah kualitas diet, status gizi dan kadar hemoglobin. Variabel bebas pada penelitian ini adalah wilayah tempat tinggal. Wilayah tempat tinggal merupakan lokasi pemukiman seseorang berdasarkan keadaan demografis. Wilayah tempat tinggal dikategorikan menjadi dua yaitu wilayah perdesaan dan perkotaan. Data lain yang dikumpulkan yaitu usia, tingkat pendidikan, pengetahuan dan aktivitas fisik.

Kualitas diet diukur dengan wawancara menggunakan Semi Quantitative-Food Frequency Questionnaire (SQ-FFQ), kemudian dihitung skor kualitas diet menggunakan formulir Diet Quality Index International (DQI-I). Kualitas diet memiliki empat komponen yaitu variasi, kecukupan, moderasi dan keseimbangan keseluruhan. Komponen variasi digunakan untuk menilai apakah asupan berasal dari sumber yang berbeda. Komponen variasi meliputi kelompok bahan makanan dan sumber protein. Komponen kecukupan untuk mengevaluasi unsur-unsur asupan makanan seharusnya tersedia dalam jumlah cukup. Komponen kecukupan terdiri dari zat gizi makro, zat gizi mikro dan serat. Komponen moderasi mengevaluasi asupan makanan dan zat gizi yang berhubungan dengan penyakit kronis dan perlu dibatasi. Moderasi terdiri dari total lemak, lemak jenuh, kolesterol, natrium dan makanan empty calory. Komponen terakhir yaitu keseimbangan keseluruhan yang menganalisis keseimbangan keseluruhan diet dalam proporsionalitas antara sumber-sumber energi dan komposisi asam lemak. Keseimbangan keseluruhan terdiri dari rasio zat gizi makro dan rasio asam lemak. Skor untuk masing-masing komponen tersebut dijumlahkan sehingga skor total DQI-I bervariasi mulai dari 0 sampai $100(0$ adalah skor terendah dan 100 merupakan skor tertinggi). Kualitas diet subjek dianggap rendah apabila skor kualitas diet $\leq 60 \% .20$

Status gizi dilihat berdasarkan indeks massa tubuh (IMT). Berat badan diukur 
menggunakan timbangan digital dengan ketelitian $0,1 \mathrm{~kg}$. Tinggi badan diukur menggunakan microtoise dengan ketelitian 0,1 $\mathrm{cm}$. IMT dianggap normal jika $\geq 18,5-25 \mathrm{~kg} / \mathrm{m}^{2}$, gizi kurang jika $<18,5 \mathrm{~kg} / \mathrm{m}^{2}$, gizi lebih jika $>25-$ $26,9 \mathrm{~kg} / \mathrm{m}^{2}$ dan obese jika $\geq 27 \mathrm{~kg} / \mathrm{m}^{2} .{ }^{21}$ Selain itu, dilakukan pengukuran lingkar lengan atas (LiLA) untuk mengetahui risiko kekurangan energi kronis (KEK) pada subjek. Lingkar lengan atas diukur menggunakan pita LiLA dengan ketelitian $0,1 \mathrm{~cm}$. Subjek dianggap berisiko KEK apabila LiLA $<23,5 \mathrm{~cm} .{ }^{13}$

Kadar hemoglobin $(\mathrm{Hb})$ diukur melalui uji laboratorium dalam satuan $\mathrm{g} / \mathrm{dL}$. Pengambilan sampel darah pada subjek dilakukan oleh petugas laboratorium. Darah diambil sebanyak 3 cc dan subjek tidak perlu dipuasakan. Kadar $\mathrm{Hb}$ dianalisis dengan metode cyanmethemoglobin. Kadar $\mathrm{Hb}$ dianggap normal apabila $\geq 12 \mathrm{~g} / \mathrm{dL} .{ }^{22}$ Tingkat pengetahuan gizi dilihat dari skor pengetahuan gizi. Subjek diberikan soal-soal pengetahuan terkait gizi. Pengetahuan gizi dianggap tinggi apabila skor $80 \%$ sampai $100 \%$, dianggap sedang jika skor $60 \%$ sampai $79 \%$ dan rendah jika skor $<60 \% .{ }^{23}$ Tingkat aktivitas fisik dilihat dari durasi, frekuensi dan jenis aktivitas yang dilakukan oleh subjek. Aktivitas fisik dianggap rendah apabila sebagian besar waktu subjek digunakan untuk sedentary lifestyle. Aktivitas fisik dianggap sedang apabila subjek melakukan kegiatan sehari-hari dan bekerja dengan job description tidak berat minimal 150 menit dalam seminggu. Aktivitas fisik dianggap tinggi jika subjek memiliki kegiatan sehari-hari dan bekerja dengan job description yang berat minimal 75 menit dalam seminggu. ${ }^{24}$

Analisis data statistik menggunakan software statistik.Analisis univariat digunakan untuk menggambarkan karakteristik subjek dengan mendeskripsikan setiap variabel. Analisis bivariat untuk melihat perbedaan kualitas diet, status gizi berdasarkan IMT dan kadar $\mathrm{Hb}$ antara wilayah perdesaan dan perkotaan. Uji Independent T-test dan Mann Whitney digunakan untuk menganalisis perbedaan kualitas diet, status gizi berdasarkan
IMT dan kadar $\mathrm{Hb}$ antara wilayah perdesaan dan perkotaan. Penelitian ini telah mendapatkan ethical clearance dari Komisi Etik Penelitian Kesehatan Fakultas Kedokteran Universitas Diponegoro-RSUP dr Kariadi Semarang dengan nomor 508/EC/FK-RSDK/VII/2018 dan sebelumnya subjek telah menandatangi surat persetujuan menjadi subjek (informed consent).

\section{HASIL}

\section{Karakteristik Subjek}

Karakteristik subjek ditunjukkan pada Tabel 1. Total subjek yang terlibat sampai akhir penelitian sebanyak 68 subjek yang terdiri dari 34 subjek pada wilayah desa dan 34 subjek pada wilayah kota. Sebanyak 35,3 persen subjek di desa menikah usia muda yaitu $<20$ tahun dan persentase ini lebih tinggi daripada subjek di kota yang hanya 11,8 persen. Subjek dengan tingkat pendidikan tinggi lulusan D3 dan S1 lebih banyak di wilayah kota, namun tingkat pengetahuan dengan kategori tinggi lebih banyak pada subjek di desa yaitu sebesar 61,8 persen. Sebagian besar subjek di kota adalah bekerja dan hanya 8,8 persen yang tidak bekerja sedangkan di desa sebanyak 44,1 persen subjek tidak bekerja dan hanya membantu orang tua di rumah.

Hasil pengukuran antropometri menunjukkan adanya perbedaan status gizi antara subjek wilayah desa dan kota (Tabel 1). Status gizi menurut kategori IMT menggambarkan subjek dengan gizi kurang lebih banyak ditemukan di desa tetapi subjek dengan ketegori gizi lebih dan obese lebih tinggi di kota. LiLA pada subjek di wilayah kota sebagian besar termasuk normal namun subjek di wilayah desa yang berisiko KEK berdasarkan LiLA sebanyak 55,9 persen. Sebagian besar subjek di kota memiliki aktivitas fisik sedang yaitu 73,5 persen sedangkan di desa sebanyak 55,9persen subjek memiliki aktivitas fisik tergolong tinggi. Ditemukan sebanyak 23,5 persen subjek di kota mengalami anemia dan hasil ini lebih tinggi dibandingkan di desa yaitu sebesar 14,7 persen. 
Tabel 1

Karakteristik Subjek berdasarkan Demografi, Pengetahuan Gizi, Status Gizi, Aktivitas Fisik, dan Status Anemia

\begin{tabular}{lllllr}
\hline \multirow{2}{*}{ Variabel } & \multirow{2}{*}{ Kategori } & \multicolumn{2}{c}{ Desa } & \multicolumn{2}{c}{ Kota } \\
\cline { 3 - 6 } & & $\mathrm{n}$ & $\%$ & $\mathrm{n}$ & $\%$ \\
\hline Usia & $<20$ tahun & 12 & 35,3 & 4 & 11,8 \\
\multirow{2}{*}{ Tingkat Pendidikan } & $20-35$ tahun & 22 & 64,7 & 30 & 88,2 \\
& SD & 5 & 14,7 & 4 & 11,8 \\
& SMP & 10 & 29,4 & 4 & 11,8 \\
& SMA & 16 & 47,1 & 11 & 32,4 \\
Tingkat Pengetahuan Gizi & Diploma/Sarjana & 3 & 8,8 & 15 & 44,1 \\
& Rendah & 2 & 5,9 & 9 & 26,5 \\
& Sedang & 11 & 32,4 & 9 & 26,5 \\
Aktivitas Fisik & Tinggi & 21 & 61,8 & 16 & 47,1 \\
\multirow{3}{*}{ Status Pekerjaan } & Tinggi & 19 & 55,9 & 9 & 26,5 \\
& Sedang & 15 & 44,1 & 25 & 73,5 \\
Status Gizi (IMT) & Tidak Bekerja & 15 & 44,1 & 3 & 8,8 \\
& Bekerja & 19 & 55,9 & 31 & 91,2 \\
& Gizi Kurang & 6 & 17,6 & 3 & 8,8 \\
& Normal & 26 & 76,5 & 25 & 73,5 \\
\multirow{2}{*}{ Risiko KEK (LiLA) } & Gizi Lebih & 0 & 0 & 3 & 8,8 \\
\multirow{2}{*}{ Status Anemia } & Obese & 2 & 5,9 & 3 & 8,8 \\
& Berisiko & 19 & 55,9 & 4 & 11,8 \\
& Tidak Berisiko & 15 & 44,1 & 30 & 88,2 \\
& Anemia & 5 & 14,7 & 8 & 23,5 \\
& Tidak Anemia & 29 & 85,3 & 26 & 76,5 \\
\hline
\end{tabular}

Berdasarkan Tabel 2, sebagian besar subjek baik di desa maupun di kota memiliki kualitas diet rendah. Konsumsi sayur dan zat besi di kedua wilayah sebagian besar belum sesuai dengan rekomendasi. Di wilayah desa sebanyak 64,7 persen subjek memiliki asupan kalsium di bawah rekomendasi dan persentase ini lebih tinggi dibandingkan wilayah kota yaitu 44,1 persen. Asupan lemak dan makanan rendah zat gizi baik di wilayah kota maupun desa termasuk berlebih.

Perbedaan usia, pendidikan, pengetahuan, status gizi menurut kategori IMT dan risiko KEK berdasarkan LiLA antara wanita prakonsepsi di wilayah desa dan kota
Tabel 3 menunjukkan bahwa terdapat perbedaan yang signifikan pada variabel usia, lama pendidikan, pengetahuan, risiko KEK berdasarkan LiLA, dan status gizi berdasarkan IMT subjek di wilayah kota dan desa. Hasil analisis pada kedua wilayah masih ditemukan subjek yang menikah dini yaitu di usia 16 tahun. Terdapat subjek dengan LiLA hanya $17 \mathrm{~cm}$ di wilayah desa bahkan di kedua wilayah juga ditemukan subjek dengan IMT hanya $16,7 \mathrm{~kg} / \mathrm{m}^{2}$ di desa dan $16,9 \mathrm{~kg} / \mathrm{m}^{2}$ di kota yang berarti subjek tergolong KEK tingkat 2. Tidak ada perbedaan signifikan pada kadar $\mathrm{Hb}$ antara subjek di kota dan desa $(p=0,116)$. Akan tetapi, masih ditemukan subjek dengan kadar $\mathrm{Hb}$ di bawah normal pada kedua wilayah. 
Tabel 2

Karakteristik Subjek berdasarkan Asupan

\begin{tabular}{|c|c|c|c|c|c|}
\hline \multirow{2}{*}{ Variabel } & \multirow{2}{*}{ Komponen } & \multicolumn{2}{|c|}{ Desa } & \multicolumn{2}{|c|}{ Kota } \\
\hline & & $\mathrm{n}$ & $\%$ & $\mathrm{n}$ & $\%$ \\
\hline \multirow[t]{2}{*}{ Kualitas Diet (skor) } & Tinggi $(>60)$ & 8 & 23,5 & 6 & 17,6 \\
\hline & Rendah $(\leq 60)$ & 26 & 76,5 & 28 & 82,4 \\
\hline \multirow[t]{3}{*}{ Kelompok Sayuran (porsi/hari) } & Baik $(\geq 3-5)$ & 2 & 5,9 & 0 & 0 \\
\hline & Cukup $(1,5-2,9)$ & 5 & 14,7 & 5 & 14,7 \\
\hline & Kurang $(<1,5)$ & 27 & 79,4 & 29 & 85,3 \\
\hline \multirow[t]{3}{*}{ Kelompok Buah (porsi/hari) } & Baik $(\geq 2-3)$ & 15 & 44,1 & 12 & 35,3 \\
\hline & Cukup $(1-1,9)$ & 11 & 32,4 & 13 & 38,2 \\
\hline & Kurang $(<1)$ & 8 & 23,5 & 9 & 26,5 \\
\hline \multirow[t]{3}{*}{ Kelompok Makanan Pokok (porsi/hari) } & Baik $(\geq 3-8)$ & 25 & 73,5 & 29 & 85,3 \\
\hline & Cukup $(1,5-2,9)$ & 8 & 23,5 & 5 & 14,7 \\
\hline & Kurang $(<1,5)$ & 1 & 2,9 & 0 & 0 \\
\hline \multirow[t]{3}{*}{ Serat (g/hari) } & Baik ( $\geq 20-30)$ & 9 & 26,5 & 5 & 14,7 \\
\hline & Cukup (10-19) & 16 & 47,1 & 13 & 38,2 \\
\hline & Kurang $(<10)$ & 9 & 26,5 & 16 & 47,1 \\
\hline \multirow[t]{2}{*}{ Protein (\% energi/hari) } & Baik $(\geq 15)$ & 12 & 35,3 & 19 & 55,9 \\
\hline & Cukup $(7,5-14)$ & 22 & 64,7 & 15 & 44,1 \\
\hline \multirow[t]{3}{*}{ Zat Besi (\% AKG/hari) } & Baik ( $\geq 100)$ & 1 & 2,9 & 2 & 5,9 \\
\hline & Cukup (50-99) & 9 & 26,5 & 9 & 26,5 \\
\hline & Kurang $(<50)$ & 24 & 70,6 & 23 & 67,6 \\
\hline \multirow[t]{3}{*}{ Kalsium (\% AKG/hari) } & Baik ( $\geq 100)$ & 2 & 5,9 & 1 & 2,9 \\
\hline & Cukup (50-99) & 10 & 29,4 & 18 & 52,9 \\
\hline & Kurang $(<50)$ & 22 & 64,7 & 15 & 44,1 \\
\hline \multirow[t]{3}{*}{ Vitamin C (\% AKG/hari) } & Baik $(\geq 100)$ & 25 & 73,5 & 20 & 58,8 \\
\hline & Cukup (50-99) & 2 & 5,9 & 3 & 8,8 \\
\hline & Kurang $(<50)$ & 7 & 20,6 & 11 & 32,4 \\
\hline \multirow[t]{2}{*}{ Total Lemak ( $\%$ total energi/hari) } & Baik $(\leq 30)$ & 11 & 32,4 & 10 & 29,4 \\
\hline & Lebih $(>30)$ & 23 & 67,6 & 24 & 70,6 \\
\hline \multirow[t]{2}{*}{ Lemak Jenuh (\% total energi/hari) } & Baik $(\leq 10)$ & 6 & 17,6 & 0 & 0 \\
\hline & Lebih $(>10)$ & 28 & 82,4 & 34 & 100 \\
\hline \multirow[t]{2}{*}{ Kolesterol (mg/hari) } & Baik $(\leq 300)$ & 20 & 58,8 & 25 & 73,5 \\
\hline & Lebih $(>300)$ & 14 & 41,2 & 9 & 26,5 \\
\hline \multirow[t]{2}{*}{ Natrium (mg/hari) } & Baik $(\leq 2400)$ & 30 & 88,2 & 34 & 100 \\
\hline & Lebih (> 2400) & 4 & 11,8 & 0 & 0 \\
\hline Makanan Rendah Zat Gizi & Baik $(\leq 10)$ & 12 & 35,3 & 8 & 23,5 \\
\hline (\% total energi/hari) & Lebih $(>10)$ & 22 & 64,7 & 26 & 76,5 \\
\hline
\end{tabular}

Tabel 3

Perbedaan Usia, Lama Pendidikan, Pengetahuan, LILA, IMT, dan Kadar Hb Antara Subjek Wilayah Desa dan Kota

\begin{tabular}{|c|c|c|c|c|c|c|c|}
\hline \multirow{2}{*}{ Variabel } & \multicolumn{3}{|c|}{ Desa } & \multicolumn{3}{|c|}{ Kota } & \multirow[b]{2}{*}{$p$} \\
\hline & Median & Min & Maks & Median & Min & Maks & \\
\hline$\overline{\text { Usia (tahun) }}$ & 20,0 & 16,0 & 29,0 & 25,0 & 16,0 & 35,0 & $<0,001^{a}$ \\
\hline Lama Pendidikan (tahun) & 12,0 & 6,0 & 16,0 & 12,0 & 6,0 & 16,0 & $0,006^{a}$ \\
\hline Pengetahuan Gizi (skor) & 86,0 & 53,0 & 100 & 73,0 & 33,0 & 93,0 & $0,028^{a}$ \\
\hline LILA (cm) & 23,0 & 17,0 & 30,7 & 26,5 & 21,8 & 33,5 & $<0,001 \mathrm{a}$ \\
\hline IMT (kg/m²) & 20,6 & 16,7 & 32,8 & 23,0 & 16,9 & 29,5 & $0,026^{a}$ \\
\hline Kadar $\mathrm{Hb}(\mathrm{g} / \mathrm{dL})$ & 13,2 & 9,8 & 16,0 & 13,0 & 8,1 & 14,6 & $0,116^{a}$ \\
\hline
\end{tabular}


Tabel 4

Perbedaan Kualitas Diet Subjek berdasarkan Wilayah

\begin{tabular}{|c|c|c|c|c|c|c|c|}
\hline \multirow{2}{*}{ Variabel } & \multicolumn{3}{|c|}{ Desa } & \multicolumn{3}{|c|}{ Kota } & \multirow[b]{2}{*}{$p$} \\
\hline & Median & Min & Maks & Median & Min & Maks & \\
\hline Kualitas Diet (skor) & 53,0 & 33,0 & 73,0 & 53,0 & 39,0 & 69,0 & $0,990^{b}$ \\
\hline Variasi (skor) & 17,0 & 8,0 & 20,0 & 17,0 & 11,0 & 20,0 & $0,426^{a}$ \\
\hline Keseluruhan (jenis/hari) & 4,0 & 1,0 & 5,0 & 4,0 & 2,0 & 5,0 & $0,369^{a}$ \\
\hline Protein (jenis/hari) & 6,0 & 2,0 & 6,0 & 5,5 & 4,0 & 6,0 & $0,001 a^{*}$ \\
\hline Kecukupan (skor) & 24,0 & 13,0 & 38,0 & 22,0 & 14,0 & 34,0 & $0,840^{\mathrm{b}}$ \\
\hline Sayuran (porsi/hari) & 0,5 & 0,1 & 4,0 & 0,5 & 0,04 & 3,1 & $0,416^{a}$ \\
\hline Buah (porsi/hari) & 1,5 & 0 & 12,0 & 1,2 & 0 & 14,4 & $0,796^{\mathrm{a}}$ \\
\hline Makanan Pokok (porsi/hari) & 3,6 & 1,3 & 6,0 & 3,4 & 2,0 & 5,7 & $0,474 \mathrm{~b}$ \\
\hline Serat (g/hari) & 13,3 & 3,2 & 60,1 & 10,1 & 3,2 & 28,9 & $0,059 \mathrm{a}$ \\
\hline Protein (g/hari) & 63,4 & 19,9 & 156,7 & 64,5 & 32,4 & 106,6 & $0,976^{a}$ \\
\hline Zat Besi (mg/hari) & 9,1 & 3,4 & 26,9 & 10,7 & 4,5 & 28 & $0,917 a$ \\
\hline Kalsium (mg/hari) & 483,0 & 114,2 & 1323,2 & 565,0 & 174,3 & 100,0 & $0,315^{a}$ \\
\hline Vitamin C (mg/hari) & 147,0 & 9,2 & 1393,6 & 110,0 & 7,2 & 458,4 & $0,451^{a}$ \\
\hline Moderasi (skor) & 12,0 & 3,0 & 21,0 & 12,0 & 6,0 & 18,0 & $0,723^{a}$ \\
\hline Total Lemak (g/hari) & 72,0 & 33,7 & 129,4 & 62,2 & 39,2 & 85,9 & $0,013^{b^{*}}$ \\
\hline Lemak Jenuh (g/hari) & 33,7 & 16,0 & 60,4 & 27,7 & 18,3 & 37,8 & $0,002^{b^{*}}$ \\
\hline Kolesterol (g/hari) & 258,0 & 26,0 & 921,9 & 237,0 & 48,5 & 443,2 & $0,303^{a}$ \\
\hline Natrium (mg/hari) & 737,0 & 135,2 & 4565,6 & 679,0 & 53,7 & 1691,9 & $0,411^{a}$ \\
\hline Makanan Rendah Zat G & 13,5 & 2,0 & 38,0 & 13,7 & 8,1 & 26,0 & $0,540 \mathrm{a}$ \\
\hline Keseimbangan Keseluruhan (skor) & 0 & 0 & 6,0 & 0 & 0 & 6,0 & $0,988^{a}$ \\
\hline Rasio Makronutrien & 0 & 0 & 6,0 & 0 & 0 & 6,0 & $0,982^{a}$ \\
\hline Rasio Asam Lemak & 0 & 0 & 0 & 0 & 0 & 0 & $1,000^{a}$ \\
\hline MUFA (mg/hari) & 16,1 & 6,0 & 46,2 & 13,1 & 7,0 & 33,6 & $0,050 \mathrm{a}$ \\
\hline PUFA (mg/hari) & 10,1 & 2,9 & 23,0 & 9,3 & 4,5 & 23,4 & $0,496^{a}$ \\
\hline Karbohidrat (g/hari) & 243,0 & 85,5 & 522,2 & 224,0 & 126,8 & 426,7 & $0,303^{a}$ \\
\hline Total Energi (kkal) & 1788,0 & 860,3 & 3478,9 & 1686,0 & 1021,4 & 2747,7 & $0,303^{\mathrm{a}}$ \\
\hline
\end{tabular}

Perbedaan kualitas diet, status gizi dan kadar hemoglobin antara wanita prakonsepsi di wilayah desa dan kota

Tabel 4 menampilkan hasil analisis perbedaan kualitas diet subjek di wilayah desa dan kota. Tidak ada perbedaan kualitas diet yang signifikan antara kedua wilayah. Begitu pula dengan komponen variasi, kecukupan, moderasi dan keseimbangan keseluruhan yang menunjukkan tidak ada perbedaan. Skor kualitas diet subjek dikedua wilayah tergolong rendah dengan rerata yang hampir sama.

Variasi jenis protein yang di konsumsi, asupan total lemak dan lemak jenuh menunjukkan adanya perbedaan dengan asupan di wilayah desa lebih tinggi dibandingkan wilayah kota. Dari Tabel 4 dapat dilihat beberapa sub komponen kecukupan asupan harian di kedua wilayah belum memenuhi rekomendasi angka kecukupan gizi (AKG) tahun 2013. Sub komponen tersebut yaitu, asupan sayur, serat, zat besi, dan kalsium.

\section{BAHASAN}

Karakteristik pengantin wanita wilayah desa dan kota memiliki perbedaan dimana pengantin wanita wilayah desayang menikah di usia muda $<20$ tahun, pendidikan rendah, dan tidak bekerja persentase nya lebih tinggi dibandingkan wilayah kota. Hasil penelitian yang dilakukan tahun 2015 menunjukkan bahwa subjek yang tinggal di desa cenderung menikah di usia muda daripada di kota dengan persentase 52,9 persen. Usia menikah yang tinggi di wilayah kota dapat disebabkan oleh kesibukan masyarakat kota untuk melanjutkan pendidikan ke jenjang yang lebih tinggi di usia muda dan faktor biaya pendidikan yang mahal menjadi alasan masyarakat desa tidak melanjutkan pendidikan. ${ }^{25}$ 
Pernikahan dini dan terjadinya kehamilan di usia muda berkorelasi dengan angka kematian dan kesakitan ibu. Wanita yang berusia kurang dari 20 tahun masih dalam masa pertumbuhan sehingga ketika mengalami kehamilan akan terjadi persaingan kebutuhan gizi dengan janin yang dikandung. Hal ini dapat menyebabkan anemia defisiensi zat gizi dan berisiko melahirkan bayi dengan berat badan lahir rendah. Selain itu, anatomi tubuhyang belum siap untuk proses mengandung maupun melahirkan dapat menimbulkan komplikasi berupa obstetric fistula. Akibatnya selama kehamilan dan persalinan dapat terjadipeningkatanrisiko keguguran, kematian janin yang dikandung, kelahiran prematur, pendarahan serta kematian ibu dan bayi. ${ }^{26,27}$

Tingkat pendidikan wanita prakonsepsi dapat mempengaruhi keadaan status gizi dan pemilihan bahan makanan.Semakin tinggi tingkat pendidikan maka akan mudah menerima hal-hal baru dan mudah menyesuaikan dengan perubahan baru serta pendidikan yang tinggi diasumsikan mempunyai pengetahuan dan akses informasi yang cukup tentang berbagai hal termasuk masalah gizi. ${ }^{28}$ Data menunjukkan persentase tingkat pendidikan subjek lebih tinggi di wilayah kota dibandingkan wilayah desa tetapi tingkat pengetahuan lebih tinggi pada subjek wilayah desa. Hal ini bertentangan dengan penelitian sebelumnya bahwa tingkat pendidikan yang rendah memungkinkan rendahnya pengetahuan tentang asupan gizi dan kesehatan. ${ }^{29}$

Tingkat pengetahuan akan mempengaruhi perilaku gizi yang berdampak pada pola kebiasaan makan. Banyak faktor yang dapat mempengaruhi tingkat pengetahuan seseorang. Faktor-faktor yang mempengaruhi tingkat pengetahuan dibagi menjadi dua yaitu faktor internal dan eksternal. Faktor internal yang meliputi pendidikan, pekerjaan, dan umur sedangkan faktor eksternal meliputi faktor lingkungan dan sosial ekonomi. ${ }^{30}$ Dari karakteristik usia sebagian besar subjek wilayah desa memiliki usia lebih muda dibandingkan wilayah kota. Hal ini dapat mempengaruhi akses informasi melalui media sosial. Penelitian sebelumnya menyebutkan bahwa pengguna internet paling banyak berada pada kelompok usia muda dan semakin tua usia responden semakin jarang menggunakan internet. ${ }^{31}$ Sebagian besar subjek di desa memiliki smartphone meskipun tinggal di wilayah pedesaan sehingga memungkinkan subjek untuk mengakses informasi terutama mengenai gizi prakonsepsi. Selain itu, ketersediaan waktu yang berbeda saat pengisian kuesioner pengetahuan gizi pada kedua wilayah juga dapat mempengaruhi hasil. Hal ini karena di wilayah desa dalam pengambilan data setiap subjek dibuat menjadi dua hari sedangkan wilayah kota hanya satu hari karena sebagian besar subjek bekerja. Subjek wilayah desa memiliki waktu lebih banyak dibandingkan subjek wilayah kota sehingga subjek wilayah desa lebih fokus dibandingkan wilayah kota saat pengisian kuesioner pengetahuan gizi.

Salah satu perbedaan karakteristik subjek wilayah desa dan kota yaitu status pekerjaan. Sebagian besar subjek wilayah kota bekerja sedangkan di wilayah desa tidak bekerja. Pekerjaan subjek wilayah pedesaan sebagian besar yaitu buruh pabrik sedangkan wilayah kota termasuk tipe white collar worker yaitu tipe pekerja yang mempunyai keterampilan khusus seperti staff accounting dan staff finance. Pekerjaan juga berkaitan dengan tingkat aktivitas fisik subjek. Data memperlihatkan bahwa aktivitas fisik subjek wilayah desa lebih tinggi dibandingkan wilayah kota meskipun tidak signifikan. Hal ini dikarenakan subjek desa banyak bekerja sebagai buruh pabrik atau staf produksi sehingga aktivitas fisik lebih berat dibandingkan subjek kota. Aktivitas fisik yang kurang menyebabkan penggunaan kalori yang dikonsumsi menjadi tidak optimal sehingga sebagian kalori disimpan oleh tubuh sebagai cadangan lemak. Apabila terjadi secara terus menerus maka akan terjadi peningkatan lemak tubuh. ${ }^{32}$ Ini sesuai dengan data bahwa LiLA subjek wilayah kota lebih tinggi dibandingkan wilayah desa begitu pula dengan status gizi berdasarkan IMT.

Hasil penelitian menunjukkan baik di wilayah desa maupun kota masih ditemukan subjek yang mengalami KEK tingkat 2. Risiko KEK berdasarkan LiLA lebih tinggi pada wilayah desa yaitu 55,9 persen dibandingkan wilayah kota 11,8 persen. Hasil penelitian sesuai dengan data Riskesdas 2013. ${ }^{3}$ Penelitian sebelumnyapada ibu hamil menyatakan bahwa ada hubungan bermakna antara aktivitas fisik yang berat dengan risiko KEK. Hal itu karena tingkat aktivitas fisik yang berat meningkatkan kebutuhan energi. ${ }^{33}$ Tingginya risiko KEK di 
wilayah desa dapat disebabkan oleh aktivitas fisik yang tinggi namun tidak disertai dengan peningkatan konsumsi makanan. Selain iu, data wawancara asupan makanan mengungkapkan bahwa sebagian besar subjek yang mengalami risiko KEK termasuk kurang asupan energi protein. Apabila asupan energi kurang maka fungsi protein untuk membentuk glukosa akan didahulukan. Pemecahan protein tersebut akan menyebabkan melemahnya otot-otot dan jika terjadi secara terus menerus akan terjadi deplesi massa otot. LiLA $<23,5 \mathrm{~cm}$ menandakan telah terjadi penurunan massa otot akibat kurangnya protein dalam tubuh dan sebagai tanda adanya risiko kekurangan energi kronis. ${ }^{34}$ Hal ini sejalan dengan penelitian sebelumnya yang menyebutkan bahwa ada hubungan antara tingkat kecukupan energi dengan risiko KEK pada ibu hamil. ${ }^{33}$ Penelitian tahun 2018 pada wanita prakonsepi juga menyatakan adanya hubungan antara asupan energi dan protein dengan kejadian KEK pada wanita prakonsepsi. ${ }^{14}$ Kejadian KEK pada masa sebelum kehamilan dapat menyebabkan suplai zat gizi ke janin tidak optimal sehingga mempengaruhi pertumbuhan dan perkembangan janin. ${ }^{9}$ Oleh karena itu, perlu adanyapencegahan kejadian KEK sejak masa prakonsepsi.

Masalah gizi selain KEK yang dilihat pada penelitian ini yaitu anemia. Baik wilayah desa maupun kota masih ditemukan subjek yang mengalami anemia. Persentase anemia pada subjek wilayah kota lebih tinggi yaitu 23,5 persen dibandingkan wilayah desa sebesar 14,7 persen. Hasil tersebut bertentangan dengan data Riskesdas 2013 yang menyatakan bahwa prevalensi anemia lebih tinggi pada ibu hamil wilayah perdesaan 22,8 persen dibandingkan perkotaan sebesar 20,6 persen. $^{3}$ Akan tetapi penelitian pada tahun 2016 pada ibu hamil di Indonesia menunjukkan prevalensi anemia di wilayah kota sebesar 38,2 persen lebih tinggi dibandingkan wilayah desa yaitu sebesar 37,9 persen. ${ }^{35}$ Penelitian di Malawian tahun 2017 juga mengungkapkan bahwa kejadian anemia lebih tinggi pada wanita perkotaan dibandingkan perdesaan. Hal ini disebabkan oleh akses makanan wanita perdesaan lebih baik pada sumber makanan yang bervariasi dibandingkan perkotaan. ${ }^{12}$ Data asupan juga menunjukkan bahwa rerata konsumsi protein lebih tinggi di wilayah desa dibandingkan kota.Meskipun prevalensi anemia pada penelitian ini tidak begitu tinggi, kejadian anemia pada wanita prakonsepsi perlu diwaspadai karena dapat berisiko jangka panjang. Wanita prakonsepsi yang mengalami anemia berisiko mengalami keguguran pada awal kehamilan. Sebuah penelitian menyebutkan bahwa kasus keguguran terjadi pada awal kehamilan di usia $<12$ minggu. ${ }^{36}$ Anemia menyebabkan gangguan gizi dan peredaran oksigen menuju sirkulasi uteroplasenter sehingga dapat secara langsung mempengaruhi pertumbuhan janin dalam kandungan melalui plasenta. ${ }^{37}$ Selain itu,anemia pada masa prakonsepsi dan berlanjut saatkehamilan dapat meningkatkan risiko persalinan prematur, retardasi pertumbuhan intra uteri (intra-uterine growth retardation, IUGR) dan kematian janin intra uterin (intrauterine fetal death, IUFD). 38,39

Asupan merupakan salah satu faktor yang mempengaruhi status gizi seseorang. Asupan rendah secara terus menerus dapat menyebabkan gizi kurang dan rendah nya kadar hemoglobin karena kebutuhan zat gizi terutama protein dan zat besi yang tidak terpenuhi. Kualitas diet adalah salah satu indikator yang dapat menggambarkan pola konsumsi makanan seseorang. Hasil penelitian ini menunjukkan bahwa kualitas diet subjek di wilayah desa dan kota memiliki rerata skor yang rendah. Rendahnya skor kualitas diet disebabkan adanya ketidaksesuaian asupan zat gizi yang terdapat pada setiap komponen kualitas diet. Kualitas diet terdiri dari empat komponen yaitu, variasi, kecukupan, moderasi dan keseimbangan keseluruhan.

Data menunjukkan bahwa tidak ada perbedaan skor yang signifikan pada tiap-tiap komponen kualitas diet. Meskipun demikian rerata skor komponen kecukupan, moderasi dan keseimbangan keseluruhan lebih tinggi pada subjek wilayah desa dibandingkan kota. Ditemukan adanya perbedaan variasi jenis protein yang di konsumsi yaitu subjek wilayah desa memiliki jenis asupan protein yang lebih bervariasi dibandingkan kota. Asupan total lemak dan lemak jenuh subjek desa lebih tinggi dibandingkan kota. Hal ini sesuai denganpenelitian sebelumnya pada wanita usia subur di wilayah desa dan kota Australia yang menyebutkan bahwa tidak ada perbedaan kualitas diet wanita usia subur di wilayah desa dan kota tetapi pola konsumsi zat gizi makro 
lebih tinggi di wilayah desa dibandingkan wilayah kota. ${ }^{40}$

Skor komponen variasi lebih tinggi pada subjek di wilayah kota namun variasi jenis protein yang dikonsumsi oleh subjek desa secara signifikan lebih tinggi. Subjek di wilayah desa mengonsumsi makanan sumber protein seperti daging, unggas, ikan, produk susu, kacang-kacangan dan telur lebih variatif dibandingkan wilayah kota. Data FFQ mengungkapkan beberapa subjek di wilayah kota ada yang tidak mengonsumsi susu, ikan, daging atau telur dalam 1 bulan terakhir.Hal ini dapat disebabkan oleh ketersediaan waktu luang di desa yang lebih banyak sehingga jenis asupan protein lebih bervariasi dibandingkan kota. Selain itu, hasil analisis penelitian ini menunjukkan adanya korelasi positif antara asupan jenis protein dengan tingkat pengetahuan. Semakin tinggi tingkat pengetahuan maka asupan jenis protein akan semakin bervariasi. Hasil ini sejalan dengan penelitian sebelumnya yang menyebutkan bahwa asupan makanan bergizi pada wanita perdesaan lebih tinggi pada subjek yang telah mengakses informasi pengetahuan tentang gizi dibandingkan subjek dengan pengetahuan gizi rendah. ${ }^{41} \mathrm{Hal}$ ini dikarenakan pengetahuan tentang bahan makanan akan mempengaruhi perilaku dalam pemilihan dan pengolahan, semakin tinggi tingkat pengetahuan gizi maka konsumsi makanan menjadi lebih baik. ${ }^{14}$

Asupan total lemak dan lemak jenuh pada subjek wilayah desa lebih tinggi dikarenakan berdasarkan hasil wawancara asupan makan adanya kebiasaan konsumsi gorengan dan jajanan seperti siomay, bakso dan cilok yang lebih tinggi dibandingkan dengan subjek wilayah kota. Rendahnya frekuensi konsumsi jajanan di wilayah kota dapat disebabkan karena kesibukan kerja sehingga ketersediaan waktu untuk makan lebih sedikit dibandingkan wilayah desa. Hal ini sesuai dengan penelitian sebelumnya yang mengungkapkan bahwa kelompok pekerja administrasi hanya makan dua kali sehari dan jarang/tidak ada makanan selingan ${ }^{42}$ Padahal penelitian lain menyatakan frekuensi camilan yang sering dapat menjadikan jumlah kalori yang dikonsumsi setara dengan saat konsumsi menu utama. ${ }^{43}$ Kontribusi yang tinggi dari makanan jajanan dapat berakibat meningkatnya asupan energi total. ${ }^{44}$ Sedangkan konsumsi sayur-sayuran pada kedua tempat, baik di desa maupun kota ditemukan samasama rendah. Kebiasaan konsumsi sayur terutama sayuran hijau pada subjek di desa dan kota masih kurang, sehingga kecukupan serat subjek ditemukan sebagian besar dalam kategori kurang.

Hasil analisis menjelaskan ada perbedaan status gizi berdasarkan IMTpada subjek di kedua wilayah meskipun rerata IMT masih tergolong normal. Persentase gemuk dan obese lebih tinggi pada wilayah kota dibandingkan desa.Penelitian sebelumnya menyebutkan bahwa prevalensi obese daerah perkotaan lebih tinggi dari pada di perdesaan masing-masing sebesar 23,8 persen dan 16,3 persen. ${ }^{45}$ Asupan subjek desa lebih tinggi dibandingkan wilayah kota terutama asupan total lemak dan lemak jenuh karena tingginya konsumsi camilan. Menurut McCory dan Campbell mengonsumsi makanan ringan atau camilan apalagi dalam frekuensi sering dapat menyebabkan asupan makanan berlebih dan berpotensi mengalami kenaikan berat badan. ${ }^{46}$ Aktivitas fisik subjek wilayah desa lebih tinggi dibandingkan wilayah kota. Penurunan aktivitas fisik subjek kota akan berakibatmenurunnya pengeluaran energi sehingga dapat meningkatkan kejadian obesitas. Hal itu memacu keseimbangan energi positif dan peningkatan simpanan lemak tubuh dalam bentuk trigliserida di dalam jaringan adiposa. Keseimbangan energi positif terjadi karena (1) peningkatan asupan dan tidak terjadi pengeluaran energi, (2) terjadi penurunan pengeluaran energi tanpa peningkatan asupan, (3) peningkatan asupan dan terjadi penurunan pengeluaran energi. Peningkatan asupan maupun penurunan energi, keduanya berpotensi menyebabkan terjadinya obesitas. ${ }^{44}$ Oleh karena itu, meskipun asupan kalori subjek wilayah desa lebih tinggi dibandingkan wilayah kota tetapi aktivitas fisik subjek di desa juga tinggi sehingga penggunaan energi lebih optimal dibandingkan wilayah kota.

Teori menyatakan anemia dapat disebabkan oleh kurang asupan zat gizi seperti, protein, zat besi, vitamin $C$, vitamin $A$, vitamin $B 6$, vitamin $B 12$, asam folat atau mangan. ${ }^{47}$ Zat besi dalam tubuh berperan penting sebagai bahan utama dalam sintesis hemoglobin, ketika cadangan besi dalam tubuh berkurang maka akan menyebabkan sintesis heme yang terganggu. Ketikaasupan zat besi yang kurang dan bioavailabilitas yang rendah maka 
cadangan besi akan digunakan sehingga dalam jangka waktu lama menimbulkan anemia gizi besi. ${ }^{48}$

Asupan zat besi subjek di kedua wilayah berdasarkan data masih tergolong rendah dan belum sesuai rekomendasi.Subjek yang tidak anemia tapi konsumsi zat besinya rendah kemungkinan masih memiliki cadangan besi dalam tubuh untuk keperluan sintesis hemoglobin.Selain itu,asupan protein dan vitamin $C$ subjek sebagian besar memenuhi kebutuhan. Protein berperan sebagai transporter zat besi sedangkan vitamin $C$ berfungsi mempercepat penyerapan zat besi. ${ }^{47}$ Rendahnya asupan zat besi tidak mempengaruhi kadar $\mathrm{Hb}$ subjek juga dapat dikarenakan ketersediaan zat gizi pendukung seperti protein dan vitamin C yang cukup sehingga penyerapan zat besi lebih optimal.

Hasil penelitian ini menunjukkan karakteristik subjek di wilayah desa yaitu, menikah di usia muda, pendidikan rendah, tidak bekerja dan tingkat aktivitas fisik tinggi sedangkan di wilayah kota sebagian besar subjek menikah usia $>20$ tahun, pendidikan tinggi, bekerja dan aktivitas fisik sedang. Kualitas diet subjek di wilayah desa dan kota masih tergolong rendah namun sub komponen variasi jenis asupan protein, total lemak dan lemak jenuh lebih tinggi di wilayah desa dibandingkan kota. Hal ini dikarenakan subjek di desa memiliki waktu luang yang lebih banyak sehingga frekuensi makan lebih sering. Ditemukan risiko KEK lebih tinggi di wilayah desa karena aktivitas fisik lebih tinggi sehingga kebutuhan energi juga lebih tinggi dibandingkan subjek kota serta diketahui subjek yang berisiko KEK juga memiliki asupan energi dan protein yang rendah. Akan tetapi kejadian anemia lebih tinggi di wilayah kota karena tingkat konsumsi protein subjek kota lebih rendah dibandingkan subjek desa. Hasil penelitian ini dapat dijadikan pertimbangan dalam pelaksanaan program/intervensi gizi pada calon pengantin agar merata tidak hanya di desa saja atau sebaliknya, tapi di semua daerah dan khususnya pada daerah-daerah yang prevalensi anemianya masih tinggi.

Keterbatasan penelitian ini adalah sulitnya menemukan subjek sesuai kriteria inklusi yaitu calon pengantin wanita usia produktif yang sudah siap menikah, karena biasanya musim pernikahan tidak terjadi di sepanjang bulan, sehingga untuk memenuhi jumlah subjek harus menunggu sampai beberapa bulan. Selain itu keterbatasan mengumpulkan subjek penelitian dalam satu waktu karena subjek banyak yang bekerja.

\section{SIMPULAN DAN SARAN}

\section{Simpulan}

Terdapat perbedaan signifikan pada variabel usia, lama pendidikan, pengetahuan gizi, risiko KEK berdasarkan LiLA, dan status gizi berdasarkan IMT subjek di wilayah desa dan kota. Akan tetapi, tidak ada perbedaan signifikan antara kadar $\mathrm{Hb}$ dan kualitas diet subjek di desa dan kota, namun dari komponen variasi ditemukan variasi jenis protein, asupan total lemak dan lemak jenuh yang dikonsumsi subjek di wilayah desa lebih tinggi dibandingkan wilayah kota.

\section{Saran}

Perlu adanya edukasi dan konseling gizi dalam mempersiapkan kehamilan pada calon pengantin wanita di wilayah desadan kota.Edukasi dan konseling gizimengenaikualitas diet yang meliputi variasi, kecukupan, moderasi dan keseimbangan keseluruhan. Secara khusus, pada wilayah desa perlu edukasi tentang gizi pada calon pengantin dengan aktivitas fisik tinggi dan usia muda $<20$ tahun.Untuk wilayahkota juga dijelaskan pentingnya aktivitas fisik agar menjaga status gizi tetap normal.

\section{UCAPAN TERIMAKASIH}

Terima kasih kepada subjek penelitian, KUA Pedurungan Kota Semarang, KUA Sumowono Kabupaten Semarang dan lembaga pemberi dana,yang dibiayai oleh hibah RPP Fakultas Kedokteran Universitas Diponegoro.

\section{RUJUKAN}

1. Perdana S, Hardinsyah, Damayanthi E. Alternatif Indeks Gizi Seimbang untuk Penilaian Mutu Gizi Konsumsi Pangan Wanita Dewasa Indonesia. Jurnal Gizi dan Pangan. 2014;9(15):43-50. https://doi.org/10.25182/jgp.2014.9.1.\%25 $p$

2. Association of State Public health 
Nutritionists. Preconception Health: The Role of Nutrition. 2015;1-10.

3. Badan Penelitian dan Pengembangan Kesehatan 2013. Riset Kesehatan Dasar (RISKESDAS). 2013;1-384.

4. Cilmiaty $R$, Indarto $D$. Hubungan Kurang Energi Kronis dan Anemia Pada Ibu Hamil dengan Status Gizi Bayi Usia 6-12 Bulan Di Kabupaten Boyolali. Penelitian Gizi dan Makanan. 2017;39(1):1-8. doi: 10.22435/pgm.v39i1.5964.1-8

5. Adiputra KP, Pinatih IGNI, Seriani L. Perbedaan Persiapan Prakonsepsi lbu Hamil Primigravida yang Mengalami Kurang Energi Kronik dan Tidak Kurang Energi kronik Di Puskesmas Gianyar 1 Periode Januari-Agustus 2017. E-Jurnal Medika Udayana. 2018;7(3):121-124.

6. Ma Q, Zhang S, Liu J, Wang Q, Shen H, Zhang $Y$, et al. Study on the Prevalence of Severe Anemia among Non-Pregnant Women of Reproductive Age in Rural China: A Large Population-Based CrossSectional Study. Nutrients. 2017:9(1298):1-15. doi:10.3390/nu9121298

7. De Benoist B, McLean E, Egli I, Cogswell $M$. Worldwide prevalence of anaemia 1993-2005. World Health Organization. 2008;3.

8. Ramakrishnan U, Grant F, Goldenberg T, Zongrone A, Martorell R. Effect of Women's Nutrition Before and During Early Pregnancy on Maternal and Infant Outcomes: A Systematic Review. Paediatric and Perinatal Epidemiology. 2012;26(Suppl.1):285-301. doi: 10.1111/j.1365-3016.2012.01281.x.

9. Jib A, Os U, Mn U. Adolescent and PrePregnancy Nutrition in Nigeria. Tropical Journal of Obstetric Gynecology. 2017;34(1):1-5. doi 10.4103/TJOG.TJOG_12_17

10. Brown JE. Nutrition Through the Life Cycle. 4th ed. USA: Cengage Learning; 2011. p. 407-412.

11. Mishra P, Ahluwalia SK, Garg PK, Kar R, Panda GK. The Prevalence of Anaemia among Reproductive Age Group ( 15-45 Yrs ) Women in A PHC of Rural Field Practice Area of MM Medical College, Ambala, India. Journal of Women's Health Care. 2012;1(3):3-5. doi: 10.4172/2167-
0420.1000113

12. Adamu AL, Crampin A, Kayuni $N$, Amberbir A, Koole O, Phiri A, et al. Prevalence and Risk Factors for Anemia Severity and Type in Malawian Men and Women: Urban and Rural Differences. Population Health Metrics. 2017;15(12):115. doi: 10.1186/s12963-017-0128-2

13. Stephanie P, Kartika SKA. Gambaran Kejadian Kurang Energi Kronis dan Pola Makan Wanita Usia Subur di Desa Pesinggahan Kecamatan Dawan Klungkung Bali 2014. E-Jurnal Medika. 2016;5(6):1-6.

14. Hubu N, Hano YH. Pengetahuan, Asupan Energy dan Zat Gizi Berhubungan dengan Kekurangan Energy Kronis pada Wanita Prakonsepsi. GJPH. 2018;1(1):15-23.

15. Suliga E. Nutritional behaviours of pregnant women in rural and urban environments. Annals of Agriculture Environmental Medicine. 2015;22(3):513517. doi: 10.5604/12321966.1167725.

16. Gao H, Stiller CK, Scherbaum V, Biesalski HK, Wang Q, Hormann E, et al. Dietary Intake and Food Habits of Pregnant Women Residing in Urban and Rural Areas of Deyang City, Sichuan Province, China. Nutrients. 2013;5:2933-2954. doi: 10.3390/nu5082933.

17. Dinas Kesehatan Kabupaten Semarang. Profil Kesehatan Kabupaten Semarang. 2016.

18. Dinas Kesehatan Kota Semarang. Profil Kesehatan Ibu dan Anak. Semarang; 2017.

19. Aminin F, Wulandari A, Lestari RP. Pengaruh Kekurangan Energi Kronis (KEK) dengan Kejadian Anemia Pada Ibu Hamil. Jurnal Kesehatan. 2014;5(2):167172.

20. Carvalho KMB de, Dutra ES, Pizato N, Gruezo ND, Ito MK. Diet Quality Assessment Indexes. Rev Nutr Campinas. 2014;27(5):605-617. https://doi.org/10.1590/141552732014000500009

21. Hizni A. Gizi Dewasa. In: IImu Gizi : Teori \& Aplikasi. Jakarta: Buku Kedokteran EGC; 2016. p. 210.

22. Susetyowati. Gizi dalam Daur Kehidupan. In: IImu Gizi Teori dan Aplikasi. Jakarta: Buku Kedokteran EGC; 2016. p. 165. 
23. Muslihah $\mathrm{N}$, Winarsih $\mathrm{S}$, Soemardini, Zakaria A, Zainudiin. Kualitas Diet dan Hubungannya dengan Pengetahuan Gizi, Status Sosial Ekonomi dan Status Gizi. Jurnal Gizi dan Dietetik Indonesia. 2013;8(1):71-76.

24. World Health Organization (WHO). Global Recommendations on Physical Activity For Health. 2010.

25. Qibtiyah M. Faktor yang Mempengaruhi Perkawinan Muda Perempuan. Jurnal Biometrika dan Kependudukan. 2014;3(1):50-58.

26. Dean S V, Lassi ZS, Imam AM, Bhutta ZA. Preconception Care : Nutritional Risks and Interventions. Reproductive Health. 2014;11(Suppl 3):1-15.

27. Fadlyana E, Larasaty S. Pernikahan Usia Dini dan Permasalahannya. Sari Pediatri. 2009;11(2):136-140.

28. Wahara W. Hubungan Pengetahuan lbu Tentang Anemia Dengan Motivasi Konsumsi Tablet Fe Selama Kehamilan Di Polindes Serimenda Sembahe Kecamatan Sibolangit Tahun 2014. Jurnal IImiah Dunia IImu. 2015;1(2):1-9.

29. Oktaviani WD, Saraswati LD, Rahfiludin MZ. Hubungan Kebiasaan Konsumsi Fast Food, Aktivitas Fisik, Pola Konsumsi, Karakteristik Remaja dan Orang Tua dengan Indeks Massa Tubuh (IMT) (Studi kasus pada Siswa SMA Negeri 9 Semarang Tahun 2012). Jurnal Kesehatan Masyarakat. 2012;1(2):542-553.

30. Sulistyoningsih H. Gizi untuk Kesehatan Ibu dan Anak. Yogyakarta: Graha IImu; 2011. p. 108.

31. Wahyudiyono. Penggunaan Teknologi Informasi dan Komunikasi Di Nusa Tenggara Barat. Jurnal Komunikasi, Media dan Informasi. 2016;5(1):29-36.

32. Gee M, Mahan LK, Scott-Stum S. Weight Management. In: Krause's, Food and Nutrition Therapy. 12th ed. Canada: Elsevier; 2008. p. 532-562.

33. Mufidah $R$, Rahayuning $D$, Widajanti $L$. Hubungan Tingkat Kecukupan Energi, Tingkat Aktivitas Fisik dan Karakteristik Keluarga dengan Risiko Kekurangan Energi Kronis Pada lbu Hamil Di Wilayah Kerja Puskesmas Dawe, Kudus. Jurnal Kesehatan Masyarakat. 2016;4(4):545551.
34. Hadi H, Nurdiati D. Tingkat Asupan Energi dan Ketersediaan Pangan Berhubungan dengan Risiko Kekurangan Energi Kronik ( KEK ) pada lbu Hamil. Jurnal Gizi dan Dietetik Indonesia. 2014;2(3):140-149.

35. Tanziha I, Damanik MR, Utama LJ, Rosmiati R. Faktor Risiko Anemia lbu Hamil di Indonesia. Jurnal Gizi Pangan. 2016;11(2):143-152. https://doi.org/10.25182/jgp.2016.11.2.\%p

36. Handayani T. Determinan Kejadian Anemia Defisiensi Zat Besi Pada ibu Hamil Di Puskesmas Nagaswidak Palembang Tahun 2017. 2017;5(2):345-356.

37. Khadijah S. Hubungan Anemia dan Usia pada Ibu Hamil dengan Kejadian Abortus Inkomplit Di RSAM Bukittinggi. Journal Endurance. 2016;1(3):158-166.

38. Kefiyalew F, Zemene E, Asres Y, Gedefaw L. Anemia among Pregnant Women in Southeast Ethiopia: Prevalence, Severity and Associated Risk Factors. BMC Research Notes. 2014;7(771):1-8.

39. Darawati M. Gizi Ibu Hamil. In: IImu Gizi Teori dan Aplikasi. Jakarta: Buku Kedokteran EGC; 2016. p. 172-173.

40. Martin JC, Moran LJ, Teede HJ, Ranasinha S, Lombard CB, Harrison CL. Exploring Diet Quality Between Urban and Rural Dwelling Women of Reproductive Age. Nutrients. 2017;9(586):1-14. doi: 10.3390/nu9060586.

41. Dewey CE, Hak C, P AHN, Charles C V. Women's Nutrient Intakes and FoodRelated Knowledge in Rural Kandal Province, Cambodia. Asia Pac J Clin Nutr. 2014;23(2):263-271.

doi: 10.6133/apjcn.2014.23.2.02.

42. Aziza Z, Dieny FF. Perbedaan Aktivitas Fisik Intensitas Berat, Asupan Zat Gizi Makro, Persentase Lemak Tubuh, dan Lingkar perut Antara Pekerja Bagian Produksi dan AdministrasiPT. Pupuk Kujang Cikampek. Journal of Nutrition College. 2015;4(2):96-103.

43. Mills JP, Perry CD, Reicks M. Eating Frequency is Associated With Energy Intake but Not Obesity in Midlife Women. Obesity. 2011;19(3):552-559.

44. Pramono A, Sulchan M. Kontribusi Makanan Jajan dan Aktivitas Fisik Terhadap Kejadian Obesitas pada Remaja Di Kota Semarang. Gizi Indon. 
2014;37(2):129-136.

45. Novitasary MD, Mayulu N, Kawengian SE. Hubungan Antara Aktivitas Fisik dengan Obesitas Pada Wanita Usia Subur Peserta Jamkesmas Di Puskesmas Wawonasa Kecamatan Singkil Manado. Jurnal eBiomedik (eBM). 2013;1(2):1040-1046.

46. McCrory M, Campbell WW. Effects of Eating Frequency, Snacking, and Breakfast Skipping on Energy Regulation: Symposium Overview. The Journal of Nutrition. 2011;(141):144-147. doi: 10.3945/jn.109.114918
47. Heuberger RA. Diseases of the Hematological System. In: Nutrition Therapy and Pathophysiology. 2 edition. Canada: Wadsworth Cengage Learning; 2011. p. 562-84.

48. Sahana ON, Sumarmi S. Hubungan Asupan Mikronutrien dengan Kadar Hemoglobin Pada Wanita Usia Subur (WUS). Media Gizi Indonesia. 2015;10(2):184-191.

http://dx.doi.org/10.20473/mgi.v10i2.184191 